\title{
Circulating Myeloid Cell
}

National Cancer Institute

\section{Source}

National Cancer Institute. Circulating Myeloid Cell. NCI Thesaurus. Code C129907.

A myeloid-derived cell found in the peripheral blood. 